\title{
The Effect of Transformational Leadership, Interactional Justice, and Job Satisfaction on Performance
}

\author{
Kuntari Dewi ${ }^{1}$, Syamsul Amar ${ }^{2}$ \\ 1Universitas Negeri Padang, Padang, Indonesia, $\square$ kd051982@gmail.com \\ ${ }^{2}$ Universitas Negeri Padang, Padang, Indonesia, $\square$ syamsul_amar3@yahoo.com
}

\begin{abstract}
This study aims to analyze the influence of transformational leadership, justice organization, physical work environment a,d job satisfaction on the employees performance of BMKG West Sumatera. This research is included in causative research with analysis of Structural Equation Modeling (SEM). The population in this study were all BMKG employees in West Sumatera with a total sample of 103 respondents. The results showed transformational leadership had a positive and significant effect on employee performance. Interactional justice has a positive and significant effect on employee performance. Physical work environment has a positive and significant effect on employee performance. Job satisfaction has a positive and significant effect on employee performance. Transformational leadership has a positive and significant effect on employee performance through job satisfaction. Interactional justice has a positive and significant effect on employee performance through job satisfaction and the physical work environment has a positive and significant effect on employee performance through job satisfaction.
\end{abstract}

Keywords: transformational leadership, interactional justice, physical work environment, job satisfaction, employee performance.

\section{Introduction}

According to Rivai (2006) performance is the real behavior of each person as work performance produced by employees in accordance with their role in the organization. Basically, employee performance is an important factor in an organization, because indicators of the success and goodness of an organization are determined by the poor performance of its employees. If the employee shows good performance, the organization will achieve the objectives in accordance with the vision and mission of a company/ organization. Good or bad employee performance is seen from its ability to complete tasks according to the work that is its responsibility. According to Luthans (2006: 65) the factors that influence employee performance are: compensation, leadership, work commitment, work environment or work atmosphere, organizational culture, involvement in the organization and work discipline. Then Siagian (2003: 78) also mentions several factors that influence employee performance, namely: salary, work environment, leadership, work motivation, work discipline and job satisfaction. Greenberg and Baron (2003: 148) describe job satisfaction as a positive or negative attitude that individuals make towards their work. Besides that Gibson (2000: 106) states job satisfaction as the attitude that employees have about their work. This is a result of their perception of work.

Job satisfaction is an important phenomenon in a company or organization, because it is related to the attitude of employees or someone's feelings towards the work at hand. According to Mangkunegara (2016) there a positive and significant relationship between job satisfaction and employee performance. The more satisfied the employee with his job, the level of employee performance will increase. Greenberg and Baron (2003: 148) describe job satisfaction as a positive or negative attitude that individuals make towards their work. Job satisfaction is an important phenomenon in a company or organization, because it is related to the attitude of employees or someone's feelings towards the work at 
hand. High job satisfaction is believed to be able to encourage an increase in employee performance which will ultimately improve overall work effectiveness.

According to Krishnan (2018) there is a positive and significant relationship between job satisfaction and performance. BMKG West Sumatra Station Office is one of the most complex organizations, because it is populated with levels of rank, age of employees, rank and class, tenure and different levels of education. Differences in employee characteristics result in the organization's environment becoming very vulnerable to trigger the emergence of job satisfaction or dissatisfaction in some employees so that it affects the employee's performance. Besides that, the problem of employee performance can also be triggered by transformational leadership, organizational justice felt by each employee and work environment. As research conducted by Dewi and Subudi (2015), the results of his research prove that transformational leadership influences job satisfaction.

Transformational leadership as described by Northouse (2013: 176) is a leadership that emphasizes the process by which people engage with others and create a relationship that increases motivation in both the leader and followers. Ritawati (2013) says that transformational leadership has a positive and significant effect on performance through satisfaction. According to Gibson et. al (2009) interactional justice simply shows where an employee is to be treated with respect and in accordance with his dignity. Interactional justice relates to feelings possessed by employees in the process of interaction in an organization involving employees with fellow employees or employees with superiors. Krishnan et al. (2018) with the research title "Examining the relationship between Organizational Justice and Job Satisfaction" The.results of this study indicate that there is a positive relationship between distributive justice, procedural justice and interactional justice to performance.

According to Gibson et al (2009) interactional justice shows the extent to which an employee is enforced with respect and in accordance with his dignity. Interactional justice relates to feelings possessed by employees in the process of interaction within an organization involving employees and fellow employees, or employees with superiors. Akbolat et al. (2015) concluding that positive perceptions of interactional justice will create job satisfaction for an employee. The Meteorology and Geophysics Agency (BMKG) is a non-departmental government institution that has the task of carrying out government duties in the fields of meterology, climatology and geophysics. BMKG has many stations and employees spread throughout Indonesia. In West Sumatra Province there are five BMKG stations including the Padang Panjang Geophysics Station I, GAW Class I Station Koto Tabang Hill, Padang Pariaman Climatology Station, Minangkabau Class II Meteorological Station, Padang Pariaman and Teluk Bayur Maritime Station. Based on the explanation above the author is interested in examining how the performance of BMKG West Sumatera employees.

\section{Methods}

This research is included in the causative research, namely determining the extent of the influence of transformational leadership, interactional justice, physical work environment and job satisfaction on the performance of the BMKG employees West Sumatra. The population in this study were all BMKG employees West Sumatra with 103 respondents. Quantitative data is presented in Table form. Data management of each variable will be processed by SEM analysis with Amos software 18.

\section{Results and Discussion}

Measurement model shows how the manifest variable (indicator) presents latent variables to be measured by testing the validity and reliability of latent variables through confirmatory factor analysis (CFA ). The confirmatory factor analysis model (CFA) can be seen in the figure below: confirmatory CFA 


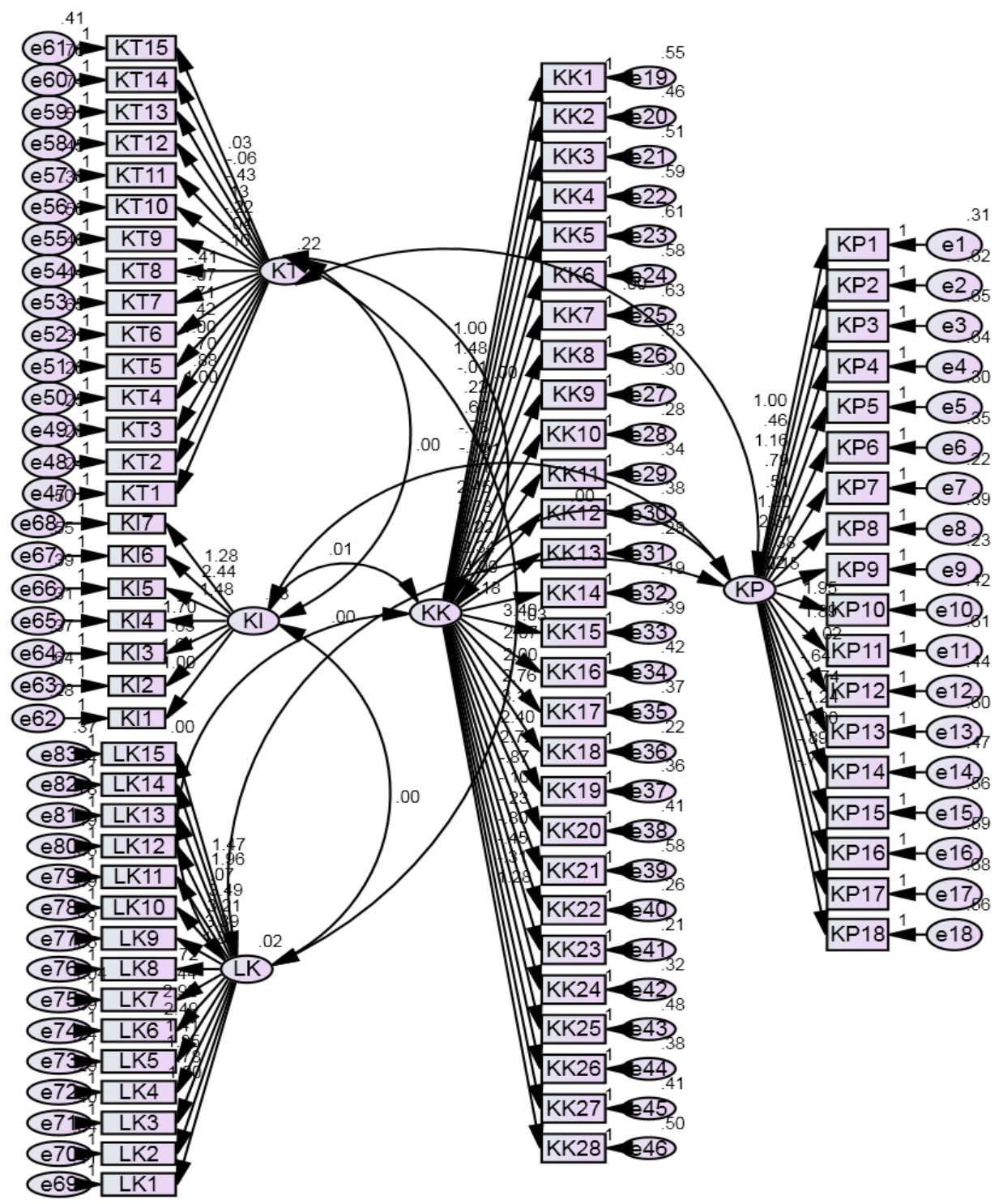

Figure 1 Model of Confirmatory Factor Analysis

The CFA analysis in the figure above gives the output of goodness of fit in the CFA analysis. If the goodness of fit output meets the fit criteria then the model is feasible to use and can be continued on structural model testing. Output of goodness of fit can be seen in the following table: 
Table 1 Test Results Goodness-of-fit Model CFA

\begin{tabular}{lllll}
\hline No & \multicolumn{1}{c}{ Index } & Value Critical & \multicolumn{1}{c}{ Results } & $\begin{array}{c}\text { Evaluation } \\
\text { Model }\end{array}$ \\
\hline 1 & Chi Square & Expected small & 5752,882 & Fit \\
\hline 2 & CMIN / DF & $<2,00$ & 1,738 & Fit \\
\hline 3 & CFI & $\geq 0,95$ & 0.984 & Fit \\
\hline 4 & RMSEA & $\leq 0.08$ & 0.085 & Fit \\
\hline 5 & TLI & $\geq 0.90$ & 0.967 & Fit \\
\hline 6 & GFI & $\geq 0.90$ & 0.808 & Marginal \\
\hline 7 & AGFI & $\geq 0.90$ & 0.882 & Marginal \\
\hline 8 & NFI & $\geq 0.90$ & 0.820 & Marginal \\
\hline 9 & PCFI & $>0.6$ & 0,634 & Fit \\
\hline & Source: Processed Primary Data (2019) & &
\end{tabular}

In Table 1 above it can be seen that in the test results with structural models, all criteria have met the criteria of goodness of fit. It can be concluded that the structural model in this study is feasible to use.

Table 2 Regession Weights

\begin{tabular}{|c|c|c|c|c|c|c|c|}
\hline & & & Estimate & SE & $\mathrm{CR}$ & $\mathrm{P}$ & Label \\
\hline KK & $<---$ & $\mathrm{KI}$ & .524 & .135 & 3,867 & $* * *$ & \\
\hline KK & $<---$ & LK & 1,192 & .246 & 4,838 & $* * *$ & \\
\hline KK & $<---$ & $\mathrm{KT}$ & .501 & .112 & 4117 & $* * *$ & \\
\hline $\mathrm{KP}$ & $<---$ & KT & .047 & .047 & 3296 & $* * *$ & \\
\hline $\mathrm{KP}$ & $<--$ & $\mathrm{KI}$ & .042 & .018 & 2,355 & .019 & \\
\hline $\mathrm{KP}$ & $<--$ & LK & .366 & .073 & 5017 & $* * *$ & \\
\hline $\mathrm{KP}$ & $<---$ & KK & 274 & .059 & 4,624 & $* * *$ & \\
\hline
\end{tabular}

Source: Processed Primary Data (2019)

Based on the results of calculation of SEM analysis with Amos in the table above, it can be explained as follows: Hypothesis 1: Transformational leadership has a positive and significant effect on job satisfaction. Hypothesis testing results found that there was a positive and significant effect of transformational leadership on the employees performance of BMKG West Sumatra. The results of calculations with Amos show a CR (Critical Ratio) of 4.117 with a probability of 0.000 .

Hypothesis 2: interactional justice has a positive and significant effect on job satisfaction. The results of hypothesis testing found that there is a positive and significant influence between interactional justice on job satisfaction of BMKG employees. The results of calculations with Amos show a CR (Critical Ratio) value of 3,867 with a probability of 0,000 .

Hypothesis 3: Physical work environment has a positive and significant effect on employees performance. The results of the hypothesis testing found that there was a positive and significant influence between the physical work environment on the job satisfaction of BMKG employees West Sumatra. The results of calculations with Amos show a CR (Critical Ratio) value of 4.838 with a probability of 0,000 .

Hypothesis 4: Job satisfaction has a positive and significant effect on employee performance. The results of hypothesis testing found that there was a positive and significant effect of job satisfaction on the employees performance of BMKG West Sumatra. The results of calculations with Amos show a CR (Critical Ratio) value of 4,624 with a probability of 0,000 . 
Hypothesis 5: Transformational leadership has a positive and significant effect on employee performance. The results of hypothesis testing found that there was a positive and significant effect of transformational leadership on the employees performance of BMKG West Sumatra. The results of calculations with Amos show a CR (Critical Ratio) value of 3.296 with a probability of 0,000 .

Hypothesis 6: Interactional justice has a positive and significant effect on performance. The results of hypothesis testing found that there is a positive and significant influence between interactional justice on the employees performance of BMKG. The results of calculations with Amos show a CR (Critical Ratio) value of 2.335 with a probability of $0.019<0.05$.

Hypothesis 7: Physical work environment has a positive and significant effect on employee performance. The results of hypothesis testing found that there was a positive and significant influence between the physical work environment on the employees performance of BMKG West Sumatra. The results of calculations with Amos show a CR (Critical Ratio) value of 5,017 with a probability of 0,000.

Hypothesis 8: Transformational leadership influences employee performance through job satisfaction. Based on the results of calculations with the sobel test, it can be seen that the results Sobel Test are $4,557(\mathrm{p}<0,05)$, while the value of the table is 1,659 , thevalue sobel test is greater than the value of the table. meaning that there is an indirect influence between transformational leadership variables with employee performance, job satisfaction acts as a mediator on the influence of transformational leadership on employee performance.

Hypothesis 9: Interactional justice affects employee performance through satisfaction. Based on the results of the calculation it was Sobel Test found that the value sobel test $(4,557)$ is large from the value of the table $(1,659)$, meaning that there is an indirect influence between interactional justice variables with employee performance, job satisfaction acts as a mediator on the influence of interactional justice on employee performance.

Hypothesis 10: Physical work environment influences employee performance through job satisfaction. Based on calculation of Sobel Test is $4.880(\mathrm{p}<0.05)$, while the value of table is 1.659 , thevalue sobel test is greater than the value of table. it means there is an indirect influence between physical work environment variables with employee performance, job satisfaction acts as a mediator on the influence of the physical work environment on employee performance.

\section{Discussion}

Transformational Leadership Influence on job satisfaction. Based on the results of these calculations it can be concluded that the relationship between transformational leadership and job satisfaction is positive. That is, if transformational leadership applied to BMKG stations is good, it will have a positive impact on job satisfaction of BMKG employee. These findings are also consistent with the research conducted by Dewi (2015), the results of his research prove that transformational leadership influences employee job satisfaction. If transformational leadership is perceived positively by employees, then employees will be more satisfied with their work.

Effect of interactional justice on job satisfaction. Based on the results of these calculations it can be concluded that the relationship between interactional justice and employee job satisfaction is positive. That is, if interactional justice applied to BMKG stations is good, it will have a positive impact on job satisfaction of BMKG employee. These findings are also reinforced by the Akbolat et al. (2015) study concluded that positive perceptions of interactional justice will create job satisfaction for an employee.

The influence of the physical work environment on job Satisfaction. Based on the results of these calculations it can be concluded that the relationship between the physical work environment and employee job satisfaction is positive. That is, if the physical work environment at the BMKG station is very conducive, it will have a positive impact on the job satisfaction of BMKG employees. Then the research is strengthened by Edward's Research (2014) stating that the work environment has a positive and significant effect on employee job satisfaction. 
Effect of job satisfaction on employee performance. Based on the results of these calculations it can be concluded that the relationship between job satisfaction and employee performance is positive. That is, if the employee feels satisfied with his work at the BMKG station it is good that it will have a positive impact on the performance of BMKG employees. These findings are also reinforced by the Mangkunegara study (2016), the results of his research show that job satisfaction has a positive affects on employee performance. The more satisfied the employee with his job, the level of employee performance will increase.

The effect of transformational leadership on employee performance. Based on the results of these calculations it can be concluded that the relationship between transformational leadership and employee performance is positive. If transformational leadership applied to BMKG stations is good, it will have a positive impact on the performance of BMKG employees. This finding was also guided by research conducted by Imran et al. (2012). The results showed that transformational leadership had a positive and significant effect on employee performance. The transformational leadership positive values to employees will have a good impact on the performance of employees.

The effect of interactional justice on employee performance. Based on the results of these calculations, it can be concluded that the relationship between interactional justice and employee performance is positive. That is, if interactional justice applied to BMKG stations is good, it will have a positive impact on the performance of BMKG employees. These findings are also reinforced by the findings of Krishnan et al. (2018) with the research title "Examining the relationship between Organizational Justice and Job Satisfaction" The results of this study indicate that there is a positive relationship between distributive justice, procedural justice and interactional justice to performance.

The influence of the physical work environment on employee performance. CR value on the influence of the physical work environment on employee performance is the highest value compared to the CR value on the influence of other variables. That is, that the physical work environment provides a strong enough role in influencing employee performance. Based on the results of these calculations it can be concluded that the relationship between the physical work environment and employee performance is positive. That is, if the physical work environment at BMKG station is very conducive, it will have a positive impact on the performance of BMKG employees. Likewise, on the contrary, an uncomfortable physical work environment will have a negative influence on the performance of BMKG employees West Sumatra. These findings are also supported by the research of Imran et al. (2012) which states that the work environment is an important factor that can affect employee / employee performance. The results of this study indicate that the work environment has a positive and significant effect on employee performance.

Effect of transformational leadership on employee performance through job satisfaction. The results of the indirect influence between transformational leadership on employee performance are higher than the direct effect. The value of indirect influence between transformational leadership on employee performance is 4.557 , while the direct influence value between transformational leadership on employee performance is 3.296. This shows that job satisfaction has a strong influence as a mediator or intermediary between transformational leadership and employee performance. If job satisfaction increases, this will have an impact on the influence of transformational leadership on employee performance. This research is supported by the research conducted by Dewi (2015), the results of his research prove that transformational leadership influences employee job satisfaction. If transformational leadership is perceived positively by employees, then employees will be more satisfied with their work. Furthermore, according to research conducted by Mangkunegara (2016), the results of his research show that job satisfaction affects employee performance. The more satisfied the employee with his job, the level of employee performance will increase. Then Ritawati's research (2013) said that transformational leadership had a positive and significant effect on performance through satisfaction. 
Effect of interactional justice on employee performance through job satisfaction. The results of this study indicate that interactional justice will affect employee performance if employee job satisfaction is improved. This finding is in line with the findings of Akbolat et al. (2015) concluding that positive perceptions of interactional justice will create job satisfaction for an employee. According to research conducted by Mangkunegara (2016), the results of his research show that job satisfaction affects employee performance. The more satisfied the employee with his job, the level of employee performance will increase.

Effect of Physical Work environment on Employee Performance through Job Satisfaction The results of this study indicate that the physical work environment will affect employee performance if job satisfaction is improved. This finding is relevant with the findings of Edward (2014) stating that the work environment has a positive and significant effect on job satisfaction. According to research conducted by Mangkunegara (2016), the results of his research show that job satisfaction affects employee performance. The more satisfied the employee with his job, the level of employee performance will increase.

\section{Conclusion}

The results showed that transformational leadership, organizational justice, physical work environment and job satisfaction had a positive and significant effect on the employees performance of BMKG West Sumatra. The highest value of direct influence is the influence of the physical work environment on employee performance. Based on these results, the authors suggest to pay attention to the conditions of a comfortable work environment. A comfortable work environment can support employee concentration in carrying out their work. Other factors must also be considered such as by creating good interactional justice and good transformational leadership and paying attention to the level of employee job satisfaction.

\section{References}

Akbolat, Isik, Yilmaz and Akca. (2015). The effect of Organizational Justice Peception on Job Satisfaction of Health Employees. International Journal of Recent Advances in Organizational Behavior and decision Sciences. 1(2).

Avolio, B.J., Gardner, W.L., Walumbwa, F.O., Luthans, F. and May, D. (2004). A look at the process by which authentic Leaders impact followers attitudes and behaviours. The leadership Quarterly. 15(8).

Bass, B.M .(1999). Two Decadesof Research and Developmentin Transformational Leadership. Europan Journal of Work and Organizational Pysicology. 8(1)

Beurend and Santos. (2017). Relation between perceived organization justice and jon satisfaction. Journal of education and research in Accounting. 67-84.

Cruceru, Raluca and Cristina Macarescu. (2009). Interactional Justice: The Link Between Employee Retention and Employment Lawsuits, Romanian Economic and Business Review, 4(4), 95-102

Darmawan, Didit. (2013). Prinsip-Prinsip Perilaku Organisasi. Surabaya: Pena Sena.

Daryanto (2013). Sari Kuliah Manajemen Produksi. Bandung :Satu Nusa.

Dessler Garry. (2010). Dasar-Dasar Manajemen Sumber Daya Manusia. Cetakan 8. Jakarta: Salemba Empat.

Dewi and Subudi. (2015). Pengaruh Kepemimpinan Transformasional terhadap Kepuasandan Turnover Intention Pada CV. Gita Karya Persada Denpasar. E-jurnal Manajemen Unud. 4(12).

Endang, Hendawati. (2010). Analisis Beban Kerja Karyawan Melalui Mutasi. Jurnal Ekonomi dan Bisnis, $5(2)$.

Ghozali, Imam. (2011). Aplikasi Analisis Multivariate Dengan Program IBM SPSS 21. Edisi 7. Badan Penerbit Universitas Diponegoro.

Gibson L James, John M Ivancevich, James H Donelly \& Robert Konopaske. (2009). Organizations Behavior Structure Processes Fourteenth Edition. McGraw-Hill, Irwin. 
Hair, F. Joseph, et al. (2010). Multivariat Data Analisys. New Jersey: Pearson EducationInc.

Hair, F. Joseph, Marcelo L.D.S.Gabriel, Vijay K. Patel. (2014). Amos Covariance-Based Structural Equation Modeling (cb-sem): guidelines on its Application as a Marketing Research Tool. Brazilian Journal of Marketing. 12(2).

Handoko, T.Hani. (2012). Manajemen Personalia dan Sumber Daya Manusia. Jakarta: Djambatan.

Hanggraeni Dewi. (2012). Manajemen Sumber Daya Manusia. Jakarta: FEUI,.

Hasibuan, Melayu. S.P. (2011).Organisasi dan Motivasi: Dasar Peningkatan Produktivitas. Jakarta: Bumi Aksara.

Hughest, Richard L et al. (2009). Leadership: Enchancing the Lessons of Experience (Sixth Edition). McGrawHill

Imran et.al. (2012). How to Boost Employee Performance: Investigating the Influence of Trnsformasional Leadership and Woek Environment in Pakistan Perspective. Middle-East Journal of Scientific Research. 11(10).

Jogiyanto. (2011). Metodologi Penelitian dengan Pendekatan Salah Kaprah. Yogyakarta: BPFE.

Kadarisman. M. (2012). Manajemen Pengembangan Sumber Daya Manusia. Jakarta: Raja Grafindo Persada.

Krisnan, Ramesh et.al. (2018). Examining the Relationship between Organizational and Job Performance. International Journal of Academic Research in Business E Social Sciences. 8(3).

Luthans, F. (2011). Organizational Behavior, An Evidence Based Approach, Twelfth Edition, McGraw Hill.

Mahbood \& Khan. (2017). Organizational Justice and Its Impact on Job Satisfaction in Public Sector Universities of Peshawar, Arabian Journal of Busuness and Management Review. 7(5)

Mangkunegara, Anwar Prabu. (2005). Manajemen Sumber Daya Manusia Perusahaan, cetakan keenam, Bandung: PT. Remaja:Rosdakarya.

Mangkunegara, Anwar Prabu and Miftahuddin. (2016). The Effect of Transformational Leadership and Job Satisfaction on Employee Performance. Universal Journal of Management. 4(4)

Mardiana. (2005). Manajemen Produksi, Jakarta: Badan Penerbit IPWI.

Moekijat. (2010). Manajemen Sumber Daya Manusia. Bandung: Mandar Maju.

Nachrowibi Nachrowi. (2009). Analisis Multivariate dengan Menggunakan SPSS dan Eviews. Yogyakarta: BPFE.

Rivai, Veithzal \& Deddy Mulyadi. (2012). Kepemimpinan dan Perilaku Organisasi. Jakarta: Rajawali Pers.

Robbins, Stephen P. \& Judge A Timothy. (2012). Organization Behavior Edition 15. New Jersey: Pearson Education.

Sekaran, Uma. (2013). Research methods for business. Metodologi penelitian untuk bisnis. Buku 2 Edisi 4. Jakarta: Salemba Empat.

Siagian, S.P. (2011). Kiat Meningkatkan Produktivitas Kerja (2nded). Jakarta: PT. Rineka Cipta.

Sopiah. (2010). Perilaku Organisasional. Yogyakarta: CV. Andi Offset,.

Sulaefi. (2017). Pengaruh keadilan Distribitif dan Posedural Kompensasi terhadap Kepuasan Kerja dan Kinerja Perawat RSU. DR. H. RM. SOESELO di Slawi, Kabupaten Tegal, Jawa Tengah. Jurnal Ekonomi dan bisnis kewirausahaan. 6(1).

Zainalipour. (2010). A study of relationship between organizational Jistice and Job Satisfaction among Teachers in Bandar Abbas middle school. Soscial and Bahavioral Sciences. 